\title{
Salting kinetics, salt diffusivities and proximate composition in osmotically dehydrated Pirarucu muscle
}

\author{
Barretto, T.L. ${ }^{\text {ab }}$; Betiol, L.F.L. ${ }^{a}$; Bellucci, E.R.B. ${ }^{a}$; Telis-Romero, J. ${ }^{a}$; Barretto, A.C. ${ }^{{ }^{*}}$ \\ ${ }^{a}$ Department of Food Technology and Engineering, Institute of Biosciences, Humanities and Exact \\ Sciences, São Paulo State University (UNESP), Rua Cristóvão Colombo, 2265, 15.054-000, São José \\ do Rio Preto, SP, Brazil \\ ${ }^{\mathrm{b}}$ Federal Institute of São Paulo - IFSP, Campus Barretos, C-1 Avenue 250, Zip Code 14781-502 \\ Barretos, São Paulo, Brazil.
}

*E-mail of the corresponding author: andreasb@ibilce.unesp.br

\begin{abstract}
Pirarucu (Arapaima gigas Schinz) farming has been encouraged and, among meat preservation techniques, the salting process is a relatively simple and low-cost method. The objective of this work was to study the sodium chloride diffusion kinetics in Pirarucu during wet salting. Limited volumes of brine $(20 \% \mathrm{w} / \mathrm{w})$ were employed with wet salting assays carried at 3, 4 and 5 brine/muscle ratios, and brine temperatures of 10,15 and $20{ }^{\circ} \mathrm{C}$. The analytical solution of Fick's second law considering one-dimensional diffusion through an infinite slab in contact with a well-stirred solution of limited volume was used to calculate the effective salt diffusion coefficients. Salt diffusivities in muscle were found to be in the range of 2.07 and $8.80 \times$ $10^{-10} \mathrm{~m}^{2} / \mathrm{s}$. The wet salting of Pirarucu is greatly influenced by temperature and by the brine/muscle ratio by volume.
\end{abstract}

Keywords: Pirarucu; Arapaima gigas Schinz; salt diffusion coefficients; brine. 


\section{Introduction}

The pirarucu (Arapaima gigas Schinz) is one of the largest freshwater fish in the world, reaching approximately 2 to 3 meters in length and up to $200 \mathrm{~kg}$ in weight in its natural habitat. The fish inhabits the Amazon River basin in South America and is one of the five most widely cultivated and marketed species in the region [1, 2, 3, 4]. It is economically and ecologically important to the riverside population due to its high commercial and nutritional value $[3,5]$. Due to its great adaptability, high market value, good sensory characteristics, expressive size and rapid development, the pirarucu has been a focus of several studies, mainly in relation to its captive breeding [6].

The increase in the pirarucu farming in aquaculture production systems has highlighted the economic significance of this species in recent years, mainly due to its nutritional quality. However, its marketing and consumption throughout the year faces some barriers due to the many changes occurring in the product because of enzyme and microbiological activities, which can affect the flavor, odor, color and texture and lead to rapid deterioration, resulting in fish of lower quality $[7,8]$.

Studies on shelf-life of food products depend on the knowledge of internal and external characteristics that can affect the speed of deterioration, such as packaging technologies, storage conditions, formulation and conservationamong others [8]. Salting is one of the oldest food conservation processes [9, 10]. The concentration of sodium chloride influences the technological properties of the food, such as water retention capacity, viscosity, texture, emulsification, influences the properties of proteins and promotes sensory acceptance [11, $12]$.

Salting is a good alternative for producing processed food because it is a relatively simple, low-cost technique and can be carried out in places with little infrastructure. Brining is a specific process of osmotic dehydration that is conducted by immersing the product in concentrated saline solution [13]. In this operation, two main mass transfer processes occur. The water migrates from the meat to the brine and solutes from the brine transfer to the meat. Consequently, changes in the composition of solids produce a decrease in the amount of water available for degradation reactions by enzymes and microorganisms [14, 15].

The diffusion of salt in meats and meat products has been the objective of some studies [16]. Diffusion is an important mass transfer phenomenon, responsible for the transport of sodium and chloride [17]. The mass transfer between the brine and the product is usually controlled by the diffusion rate of the solutes. Diffusion rates are calculated using solution diffusion coefficients for solids [18]. Food and foodstuffs present irregular shapes and have regions of different compositions that make the mathematical modeling difficult and some alternatives should be considered to deal with the heterogeneity of materials $[16,19,20]$. 
Water loss and absorption of solids during osmotic dehydration have been modeled using Fick's second law. Some studies use analytical solutions for transfer of one-dimensional mass based on laboratory studies carried out with a great excess of agitated solution, in order to ensure a variation in the composition of the solution and simplify the calculations involved [21]. To determine the effective diffusivity of salt in caiman meat, Romanelli \& Felício [22] used the same approach. However, the management of large volumes of solution is an obstacle to the process at an industrial scale, leading to an increase in production costs.

The knowledge of the diffusion rates is important, as it allows the correct determination of the necessary processing time, having control over the exact final concentration of salt and its distribution in the product. Several articles have been published on mass transfer and diffusion of salt in meat and fish products $[23,24]$. So, the aim of this study was to evaluate the proximate composition of the pirarucu raw material and investigate the sodium chloride diffusion kinetics in pirarucu muscle during wet salting.

\section{Materials and Methods}

This study focused on the sodium chloride diffusion in pirarucu muscle during the wet salting process using a limited volume of brine $(20 \% \mathrm{w} / \mathrm{w})$. The experiments were developed and done in the meat and meat products laboratory of the Department of Engineering and Food Technology of the Sao Paulo State University - UNESP-IBILCE.

The material used in this study consisted of a frozen Pirarucu fillets (Arapaima gigas Schinz) purchased from a single supplier, in a local supermarket in the city of Manaus (Brazil). The fillets were transported to UNESP-IBILCE (São José do Rio Preto, Brazil), stored under freezing and thawed under refrigeration temperature for 24 hours for evaluation of its physical characteristics, such as size and weight, and also the proximate composition, before salting. Moisture, ash and protein contents were determined according to the AOAC [25] method. The lipid content was determined, following the method described by Bligh \& Dyer [26].

Sodium chloride solution was used as the osmotic agent. The sodium chloride used was of food grade, the other chemical compounds used for the determinations of sodium chloride, proteins and lipids were of analytical grade.

Experiments were carried out with a brine concentration of $20 \%(w / w)$, at temperatures of 10,15 and $20^{\circ} \mathrm{C}$ and volume ratios of brine/muscle $\left(\mathrm{V}^{\mathrm{L}} / \mathrm{V}^{\mathrm{S}}\right)$ of 3,4 and 5.

Fillet densities before salting and at different periods after salting were measured according to the liquid displacement method [13]. Brine densities were measured by means of a pycnometer at $25^{\circ} \mathrm{C}$. 
Fillets were weighed and placed inside flasks of $500 \mathrm{ml}$ containing brine at a predetermined volume, temperature and salt concentration. The flasks were then maintained in a refrigerated orbital agitator, being removed at different time intervals, when the brine was drained and weighed and the fillets were dried with absorbent paper, weighed and ground. Two aliquots for salt content, estimated as the ash contents in a muffle furnace at $550{ }^{\circ} \mathrm{C}$. Two aliquots of brine were taken to measurethe salt content. The salt content was obtained according to the Mohr method [27].

The governing equation for the unsteady-state one-dimensional diffusion in a plane slab was given by Fick's second law, also called the diffusion equation, and the analytical solution of the stated problem was given by Crank [28] as:

$$
\frac{M_{t}}{M_{\infty}}=1-\sum_{n=1}^{\infty} \frac{2 \alpha(1+\alpha)}{1+\alpha+\alpha^{2} q_{n}^{2}} \exp \left(\frac{-D_{\text {eff }} q_{n}^{2} t}{L^{2}}\right)
$$

where $\mathbf{M}_{t}$ is the total amount of solute in the solid at time $t, \mathbf{M}_{\infty}$ is the corresponding quantity at equilibrium, $\mathrm{L}$ is half of the slab thickness and $\mathrm{q}_{\mathrm{n}}$ are the non zero positive roots of the equation

$$
\tan \mathrm{q}_{\mathrm{n}}=-\alpha \mathrm{q}_{\mathrm{n}}
$$

In order to adjust equation (1) to the experimental data and obtain the effective diffusivity values, parameters $\mathrm{m}, \alpha$, and qn were determined according to Telis et al. [13].

The effective diffusivities were obtained by a non-linear adjustment of the first six terms of the series corresponding to equation (1), which was performed using the Statistica software (StatSoft Inc., V.7.0).

\section{Results and discussion}

The proximate composition of Pirarucu muscle is shown in Table 1. Similar results were found by Martins et al. [29], when analyzing the proximal composition of pirarucu muscle. 
Barretto,T. L.; Betiol, L. F. L.; Bellucci, E. R. B.; Telis-Romero, J.; Barretto, A. C. S.

Table 1. Proximal composition of the Pirarucu muscle (n=3).

\begin{tabular}{cc}
\hline & $\begin{array}{c}\text { Proximate composition (\%) } \\
\text { (mean } \pm \text { standard deviation) }\end{array}$ \\
\hline Moisture & $78.99 \pm 0.07$ \\
Protein & $20.30 \pm 0.21$ \\
Lipid & $0.41 \pm 0.17$ \\
Ash & $1.08 \pm 0.07$ \\
\hline
\end{tabular}

The results for the effective diffusivity of salt at each temperature studied in the three brine/muscle ratios are shown in Table 2.

Table 2. Effective diffusivity at different brine/muscle ratios and temperatures during wet salting of Pirarucu.

\begin{tabular}{ccc}
\hline Brine/muscle ratio & Temperature $\left({ }^{\mathbf{0}} \mathbf{C}\right)$ & $\begin{array}{c}\text { Effective diffusivity } \mathbf{~ 1 0} \mathbf{1 0}^{\mathbf{1 0}} \\
\left(\mathbf{m}^{\mathbf{2}} / \mathbf{s}\right)\end{array}$ \\
\hline \multirow{2}{*}{3} & 20 & 8,79 \\
& 15 & 5,30 \\
& 10 & 2,07 \\
\hline \multirow{2}{*}{4} & 20 & 8,67 \\
& 15 & 5,62 \\
& 10 & 2,77 \\
\hline & 20 & 8,80 \\
& 15 & 5,71 \\
& 10 & 3,17 \\
\hline
\end{tabular}

Table 2 shows that the brine/muscle ratio has a low effect, since effective diffusivities were very similar for the different ratiosat the same temperatures. Similar behavior was observed by Medina-Vivanco et al. [30] when they studied tilapia muscle.

Effective diffusivities increased with increasing temperatures (Table 2) for all brine/muscle ratios. Similar results were observed by Telis et al. [13] who studied salting diffusivities in caiman muscle. Low temperatures are recommended because fish is a very perishable food. Brás \& Costa [31] used salting temperatures from $12{ }^{\circ} \mathrm{C}$ to $18{ }^{\circ} \mathrm{C}$ for salting different fishes. According to Chiralt et al. [32], higher temperatures not only affect the rate of diffusion 
phenomenon but also may affect the viscoelastic properties of the solid matrix, with a softening of the structure accompanying the temperature increase. An additional effect in salt gain rates could arise from the reduction in brine viscosity at higher temperatures.

Salted fish products have a long shelf life due to their low water activity and the flora selection that a high salt content media implies [31].

\section{Conclusions}

Salt effective diffusion coefficients are in the range from 2.07 to $8.80 \times 10^{-10} \mathrm{~m}^{2} / \mathrm{s}$.

The wet salting process of pirarucu is great influenced by temperature: the higher the temperature in the wet salting process, the higher the effective diffusion coefficients; and, to a lesser extent, by the brine/muscle volume ratio though lower temperatures are better because fish is a perishable food.

\section{References}

[1] Torres, F. F., Troncoso, O. P., Nakamatsu, J., Grande, C. J., \& Gomez, C. M. (2008). Characterization of the nanocomposite laminate structure occurring in fish scales from Arapaima gigas. Materials Science and Engineering, 28(8), 1276-1283.

[2] Currey, J. D. (2010). Mechanical properties and adaptations of some less familiar bony tissues. Journal of the Mechanical Behavior of Biomedical Materials, 3(5), 357-372.

[3] Castello, L. (2008). Nesting habitat of pirarucu Arapaima gigas in floodplains of the Amazon. Journal of Fish Biology, 72, 1520-1528.

[4] Watson, L. C., Stewart, D. J., \& Teece, M. A. (2013) Trophic ecology of Arapaima in Guyana: giant omnivores in Neotropical floodplains. Neotrop Ichthyol, 11, 341-349.

[5] Castello, L., Stewart, D. J., \& Arantes, C. C. (2011). Modeling population dynamics and conservation of arapaima in the Amazon. Reviews in Fish Biology and Fisheries, 21(3), 621-640.

[6] Cavero, B. A. S., Pereira-filho, M., Roubach, R., Ituassú, D.R., Gandra, A.L., \& Crescêncio, R. (2003). Efeito da densidade de estocagem na eficiência alimentar de juvenis de pirarucu (Arapaima gigas) em ambiente confinado, Acta Amazonica, 33 (4), 631-636.

[7] Baslar, M., Kılıc-lı M., \& Yalınkılıc, B. (2015). Dehydration kinetics of salmon and trout fillets using ultrasonic vacuum drying as a novel technique. Ultrason Sonochemistrym, 27, 495-502.

[8] Teodoro, A. J., De Andrade, E. C. B., \& Mano, S. B. (2007). Avaliação da utilização de embalagem em atmosfera modificada sobre a conservação de sardinhas (Sardinella brasiliensis), Ciência e Tecnologia de Alimentos, 27 (1), 158-161.

[9] Albarracín W., Sánchez, I. C., Grau, R. \& Barat, J. M. (2011). Salt in food processing; 
usage and reduction: a review, International Journal of Food Science and Technology, 46 (7), 1329-1336.

[10] Nguyen. M. V., Thorarinsdottir, K. A., Gudmundsdottir, A., Thorkelsson, G., \& Arason, S. (2011). The effects of salt concentration on conformational changes in cod (Gadus morhua) proteins during brine salting, Journal of Food Chemistry, 125(3), 1013-1019.

[11] Costa-Corredor, A., Muñoz, I., Arnau, J., \& GouIon, P. (2010). Uptakes and diffusivities in pork meat brine-salted with $\mathrm{NaCl}$ and K-lactate, LWT - Food Science and Technology, 43 (8), 1226-1233.

[12] Nguyen, M. V., Arason, S., Thorarinsdottir, K. A., \& Thorkelsson, G. A. (2010). Influence of salt concentration on the salting kinetics of cod loin (Gadus morhua) during brine salting, Journal of Food Engineering, 100(2), 225-231.

[13] Telis, V. R. N., Romanelli, P. F., Gabas, A. L., \& Telis-Romero, J. (2003). Salting kinetics and salt diffusivities in farmed Pantanal caiman muscle, Pesquisa Agropecuária Brasileira, 38(4), 529-535.

[14] Sabadini, E., Carvalho, B. C., Sobral, P., \& Hubinger, M. D. (1998). Mass transfer and diffusion coefficient determination in the wet and dry salting of meat, Drying Technology, 16 (9/10), 2095-2115.

[15] Barat, J. M., Grau, R., Ibáñez, J. B., Pagan-Moreno, M. J., Flores, M., \& Toldrá, F. (2006). Accelerated processing of dry-cured ham. Part I. Viability of the use of brine thawing/salting operation Meat Science, 72 (4), 757-765.

[16] Graiver, N., Pinotti, A., Califano, A., \& Zaritzky, N. (2009). Mathematical modeling of the uptake of curing salts in pork meat, Journal of Food Engineering, 95(4), 533540 .

[17] Barat, J. M., Rodríguez-Barona, S., Andrés, A., \& Fito, P. (2003). Cod salting manufacturing analysis, Food Research International, 36(5), 447-453.

[18] Floury J., Rouaud, O., Le Poullennec, M., \& Famelart, M. H. (2009). Reducing salt level in food: Part 2. Modelling salt diffusion in model cheese systems with regards to their composition, LWT Food Science and Technology, 42(10),1621-1628.

[19] Alizadeh, E., Chapleau, N., de-Lamballerie, M., \& Le-Bail, A. (2009). Impact of freezing process on salt diffusivity of seafood: application to salmon (Salmo salar) using conventional and pressure shift freezing, Food Bioproccess Technology, 2(3), 257-262.

[20] Aursand, I.G., Veliyulin, E., Böcker, U., Ofstad, R., Rustad, T., \& Erikson, U. (2008). Water and salt distribution in Atlantic Salmon (Salmo salar) studied by low-field $1 \mathrm{H}$ NMR, $1 \mathrm{H}$ and 23Na MRI and light microscopy: effects of raw material quality and brine salting J.Agric. Food Chem., 57(1), 46-54. 
[21] Raoult-wack, A. L. (1994). Recent advances in the osmotic dehydration of foods. Trends in Food Science and Technology, Oxford, 5, 255-260.

[22] Romanelli, P. F., \& Felício, P. E. (1995). Estudo da salga da carne de jacaré do Pantanal Caiman crocodilus yacare (Daudin, 1802) (Reptilia-Crocodilia). Ciência e Tecnologia de Alimentos, 15(3), 251-254.

[23] Martins, M. G., Martins, D. E. G., \& Pena, R. S. (2015). Drying kinetics and hygroscopic behavior of pirarucu (Arapaima gigas) fillet with different salt contents, LWT Food science and Technology, 62(1), 144-151.

[24] Andreeta-Gorelkina, I. V., Gorelkin, I. V., \& Rustad, T. (2016). Determination of apparent diffusion coefficient in balls made from haddock mince during brining, Journal of Food Engineering, 175, 8-14.

[25] Association of Official Analytical Chemists. (2007). Official Methods of Analysis. 18ed. Horwitz, W. (Ed.) Washington, DC, Revisão 2.

[26] Bligh, E. G.; Dyer, W. J. (1959). A rapid method for total lipid extraction and purification. Canadian Journal of Biochemistry and Physiology, 37, 911-917.

[27] James, C.S. (1995). Analytical chemistry of foods. Glasgow: Blackie Academic \& Professional, $177 \mathrm{p}$.

[28] Crank, J. (1975). The mathematics of diffusion. 2nd ed. Oxford: Clarendon, 414p.

[29] Martins, M. G., Martins, D. E. G., Pena, R. S. (2017). Chemical composition of different muscle zones in pirarucu (Arapaima gigas). Food Science and Technology, 37(4), 651-656.

[30] Medina-Vivanco, M.; Sobral, P.J.A.; Hubinger, M.D. Mass transfer during dewatering and salting of tilapia for different volume brine to fillets ratios. In: International Drying Symposium, 11., 1998, Halkidiki, Proceedings of the 11th International Drying Symposium, Thessaloniki: Mujumdar, A.S. (Ziti Publishing Company), 1998. v.A, p.852-859.

[31] Brás, A.; Costa, R. (2010). Influence of brine salting prior to pickle salting in the manufacturing of various salted-dried fish species. Journal of Food Engineering, 100, 490-495.

[32] Chiralt, A.; Fito, P.; Barat, J.M.; Andrés, A.; González-Martínez, C.; Escriche, I.; Camacho, M.M. (2001). Use of vacuum impregnation in food salting process. Journal of Food Engineering, 49, 141-151. 